\title{
A REVIEW OF THE NEW WORLD ONYCHOPHORA WITH THE DESCRIPTION OF A NEW CAVERNICOLOUS GENUS AND SPECIES FROM JAMAICA*
}

\author{
By Stewart B. Peck \\ Department of Biology, Carleton University \\ Ottawa, Ontario $\mathrm{KIS}_{5} \mathrm{~B} 6$, Canada
}

Few animals are as avidly sought and as rarely found by invertebrate zoologists in the American tropics as are onychophorans. Yet, attempting to determine any specimens which one is fortunate enough to find can be a frustrating experience because of the scattered and incomplete literature.

In December 1972, while engaged in a survey of the invertebrate cave fauna of Jamaica, I discovered an eyeless and depigmented onychophoran. At that time, I knew that the only other known species of cave-adapted (troglobitic) onychophoran, Peripatopsis alba Lawrence I93I, was from one cave in South Africa. To evaluate the status of the Jamaican troglobitic species I undertook a review of the literature of New World Onychophora, and an examination of some 300 specimens in the collections of the Museum of Comparative Zoology (Harvard University) and the Institute of Jamaica. As a result, I have concluded that a summary of the literature on the systematics and distribution of New World onychophorans would be of interest, with the description of the new genus and species.

General treatments of Onychophora morphology, anatomy, and biology are those of Cuenot (1949), Zacher (1933), Kaestner (1968), Barnes (1968) and the references cited in these and other invertebrate texts.

The only systematic treatment of the Onychophora of the world is that of Bouvier (1905, 1907). Sedgwick (1908) reviewed the classification but did not formally add to it. Cuénot (1949) and Brues, Melander and Carpenter (1954) characterize the families and subfamilies of the world. No work unites what is known of all New World species. Brues (I9II) presented a key for some species from the Caribbean and surrounding mainlands, adapted from Bouvier. Clark ( I913a) revised the American species on a generic level, and (I9r3b) gave an annotated list of species. Keys for the West Indian species are available only for the Islands of Hispaniola (Brues, 1935) and Jamaica (Arnett, 196r). Clark and Zetek

*Manuscript received by the editor July 10, 1975. 
(1946) gave a key for species known from the Canal Zone and adjoining regions.

Distribution has been discussed by many, including Brinck (1956), Brues (1923) and Clark (1913a, I9I3b, I9I5a, b). The circumtropical distribution of the family Peripatidae and the generally south temperate distribution of the family Peripatopsidae have led several authors to speculate that these distributions have been achieved through a Gondwana or continental drift mechanism (for instance, Cuénot, 1949; Hutchinson, 1928). However, although continental drift may be a fact, onychophoran distributions have not necessarily been controlled by it alone, and active, dynamic biological factors were probably more important in forming the distributions (Brinck, 1956; Darlington, 1965).

Since the summary papers by Bouvier and Clark, several species have been described and others have been placed in synonymy. The following key to the genera and list of species unites this dispersed literature and hopefully will provide a basis for encouraging further studies.

Key to the families and genera of New World onychophorans

Ia. Sexual opening between last pair of legs (Fig. I) ; Peripatopsidae, Peripatoidinae; south-temperate distribution in southern and central Chile. Metaperipatus

Ib. Sexual opening between penultimate pair of legs (Fig. 2); Peripatidae, Peripatinae.

2a. Nephridial tubercles (urinary papillae) of fourth and fifth legs indenting proximal margin of third creeping pad band on leg, usually dividing third pad into two segments (Fig. 3); four or five creeping pads; four foot papillae, 2 on each side of foot.

Oroperipatus

2b. Not the above combination; nephridial tubercles of fourth and fifth legs perhaps connected to third pad and indenting its proximal margin, but opening in space between third and fourth creeping pads, usually indenting fourth pad or rarely dividing fourth pad into two segments (Figs. 4, 7) ; usually four (rarely five or three) creeping pads (Fig. 4); three or four foot papillae.

3a. Four foot papillae (three anterior and one posterior, or rarely two anterior and two posterior) (Fig. 4); El Salvador.

Heteroperipatus

3b. Three foot papillae (two anterior and one posterior, Fig. 7).. 4 
4a. Twenty-four transverse dorsal folds to each segment, only slightly distinct because of numerous anastomoses and irregularities in grooves which separate them; 37 to $4 \mathrm{I}$ pairs of legs; Jamaica.

Plicatoperipatus

4b. Twelve transverse dorsal folds to each segment, separated by continuous grooves except at level of legs where some grooves usually bifurcate; 36 or fewer pairs of legs.

\section{5}

5a. Eyeless; 22 or 23 pairs of legs; Jamaica. ......... Speleoperipatus

5b. With eyes; 27 to 36 pairs of legs. ....................................... 6

6a. Primary papillae of dorsal surface with a quadrangular base separated by straight grooves parallel with axis of body, dorsal body folds apparently divided by grooves; accessory papillae usually small and few in number.

Macroperipatus

6b. Primary papillae of dorsal surface with a rounded base, dorsal body folds usually appearing undivided; accessory papillae with diverse degrees of development.

7a. Primary papillae of dorsal surface with great size differences in all ages, some very predominant, cylindrical, the other conical, smaller, usually three of the smaller or accessory papillae between two of the larger ones; the primary papillary tubercles separated by rather broad intervals where the accessory papillae occur; crural tubercles in male usually present on more than two pregenital pairs of legs.

Peripatus

7b. Primary papillae of dorsal surface all of one type; in medium or large specimens these papillae intergrading through all sizes, while in small specimens some are conspicuously larger, papillae closely set though with occasional accessory papillae between them; crural tubercles in male present on only the two pregenital pairs of legs.

Epiperipatus

I find it difficult to separate the last two genera with certainty. They have been used commonly as subgenera of Peripatus sensu lato and this might be a better arrangement in view of their lack of external distinctness. A study of the integumentary papillae with a scanning electron microscope (Peck, in preparation) might help to clarify the utility of these characters in Peripatus and Epiperipatus. Froehlich (1962) noted the need for a thorough review and revision of the complicated taxonomy of the New World onychophorans. This should be based on internal as well as superficial external characters. There is probably as much future work in the detection of synonyms as there is in finding and describing new species. As long ago as 1913, Clark (1913b) stated that "it is 
astonishingly easy to make mistakes in their determination." This is still true, partly because no key to the species exists. It was beyond the intent of this study to prepare one.

In the following list, references to Bouvier (1905, 1907) and Clark (1913a, I9I3b, I9I5a) are not individually given because they apply to almost all species. Also, dates and literature citations to descriptions of Bouvier (1905, 1907) and earlier are not given, because they may be found in these works. The word "seen" indicates specimens from the Museum of Comparative Zoology and the Institute of Jamaica on which some data are based. All new records reported here are based on specimens of the Museum of Comparative Zoology. A history of synonymy of each species is not given because the intention of the list is only to report presently accepted species and their documented localities.

\section{Family Peripatopsidae \\ Metaperipatus Clark, I9r3a}

Type species. Peripatus blainvillei Blanchard, 1847. By original designation and by monotypy.

Distributed only in southern and central Chile.

M. blainvillei (Blanchard). Southern Chile. Loncoche; Pucón; Palguin; San Carlos; Chiloé Island; Corral; Volcán Villarica; Enero, in Cordillera Peluda in Valdivia Prov.; Contulmo, in Cordillera Nahuelbuta separating Mallerco and Arauco Provinces; Buchoco valley between Lake Lanalhue and sea; south of Cañete, Io $\mathrm{km}$ from Contulmo. Bouvier, I928; Claude-Joseph, 1927, 1928; Gravier and Fage, I925; Johow, I9I I.

M. costesi (Gravier and Fage), 1925. Chile: Prov. Colchagua; Marga Marga near Santiago; "central Chile." Gravier and Fage, 1925.

M. umbrinus (Johow), I9I I. Chile, near Zapallar, on coast of Aconcagua Prov., at $32^{\circ} 33^{\prime} 20^{\prime \prime}$ S. lat. Johow, I9II.

Family Peripatidae

Epiperipatus Clark, I913a

Type species. Peripatus edwardsii Blanchard, I847. By original designation.

Distribution. From Santarem, Brazil, through French Guiana, Surinam, Guyana, Trinidad, Tobago, and Grenada and westward in South America to Central America and north through Nicaragua 
to Guatemala and possibly British Honduras (Belize).

E. barbouri (Brues), I9I I. Grenada: Grand Etang, $2000 \mathrm{ft}$. seen. Carriacou (?), seen. Tobago: Scarborough. Brues, I9II, I9I4; Clark, 1937.

E. biolleyi (Bouvier). Honduras: San Juan Pueblo. Brues, I925. British Honduras: near Benque Viejo (?), seen. Costa Rica: "La Estrella"; Parismina; San José; Surubres, near San Maeto; fruit farm near Siquirres, 6.vi.r930, Waldeck, I, new record; Turrialba, 6.vii.1956, C. Gans, 4, new record; Turrialba, 25.vii-r 5.viii.1965, A Chickering, 6, new record; Talamanca, no other data, 4, new record; Orotina, 30 Aug. I920, E. R. Dunn, 2 in hollow tree $6 \mathrm{ft}$. above ground, new record. Panama: El Ceremeño. Brues, I9II; Clark, I937; Clark and Zetek, I946; Picado, I9I I.

E.brasiliensis brasiliensis (Bouvier). Brazil: Santarém. Venezuela: Mérida. Bouvier, 1908.

E. brasiliensis vagans Brues, 1925. Canal Zone: Barro Colorado Island, seen; Las Cascadas, seen; Fort Sherman, seen; Río Chinilla, seen; Balboa. Panama: San Pablo, seen; Río Tapia, seen. Brues, 1925 ; Clark and Zetek, 1946.

E.edwardsi (Blanchard). Brazil: Rio Guamá, Belém do Pará; Pôrto Cachoeira, Rio Doce, Espírito Santo State. French Guiana: Cayenne. Surinam: Paramaribo. Trinidad (?). Venezuela: Haute Sarare; Bas Sarare; Mérida; Valencia; Caracas, seen. Colombia: Santa Marta Mts., seen; Cincinnati Coffee Plantation in Santa Marta Mts., seen. Panama: Panama Station: Darién; El Cermeño; Balboa. Canal Zone: Barro Colorado Island, 3.viii.r925, C. W. Dodge, I, new record; Barro Colorado Island, I7-19.iii.1967, Patterson exp., 3, new record. Arnett, I96r; Bouvier, 1906; Brues, 1914, 1925; Clark and Zetek, 1946; Froehlich, I968.

E. evansi (Bouvier). Guyana: east bank of Demerara River.

E. imthurmi (Sclater). Surinam: Paramaribo, seen. French Guiana: Cayenne; Haut Carsevenne. Guyana: Essequibo; Georgetown (Demerara); Maccasseema on Pomeroon River; Hoorubea on Demerara River; Dunoon; Wakapa; Issororo. Trinidad. Colombia: Santa Marta, Cincinnati Coffee Plantation, $3000 \mathrm{ft}$. , seen. Brues, 19I4, I925 ; Clark, I915b; Froehlich, 1968.

E. isthmicola (Bouvier). Costa Rica: San José; Cachí; Santa Clara, Colombiana Farm, seen; Hamburg Farm, I.iii.I930, F. Nevermann, one on dry wood under loose bark, new record; Guápiles, 7 Aug. 1920, E. R. Dunn, 4, new record; Navarro, 22 Aug. 1920, E. R. Dunn, 8, new record; Zent, 22-30 July 1920, E R. Dunn, 6, new record. Brues, 1925. 
E. lewisi Arnett, 1961. Jamaica: John Crow Mts., Io mi. SW Priestmans River; $5 \mathrm{mi}$. SW Priestmans River, I $500 \mathrm{ft}$.; I mi. WSW Ecclesdown; all in Portland Parish, seen.

E. nicaraguensis (Bouvier). Nicaragua: Matagalpa; San Benito. E. simoni (Bouvier). Brazil: Pará; Breves, on Marajó Island. Venezuela: Caracas. Clark, I9I3c; Clark and Zetek, 1946.

E. trinidadensis trinidadensis (Stuhlmann). Trinidad: Port of Spain, seen; Maraval Valley, seen; Laventille, seen; Simla, I 5.iv. 1964, A. M. Chickering, I, new record; Simla, I960, C. Carter, I, new record. Brues, I9I4.

E. trinidadensis broadwayi Clark, 1913. Tobago, seen. Clark r9r3c.

E. tucupi Froehlich, 1968. Brazil: Pará.

E. vespucci Brues, I914. Colombia: Santa Marta Mts., Cincinnati Coffee Plantation, $2300 \mathrm{ft}$., seen.

\section{Heteroperipatus Zilch, I954a}

Type species. Heteroperipatus engelhardi Zilch, 1954a. By original designation and by monotypy.

Known only in El Salvador and Panama.

H. engelhardi Zilch, 1954. El Salvador: Finca El Carmen, Volcán San Vicente, I IOO-I $300 \mathrm{~m}$, in litter-filled grooves in coffee plantation.

H. clarki (Dunn), 1943. New combination, suggested by Zilch, 1954a. Panama: Azuero Peninsula.

\section{Macroperipatus Clark, i913a}

Type species. Peripatus torquatus von Kennel, i883. By original designation.

Distribution. Rio de Janeiro north to French Guiana, Guyana and Trinidad, west to Panama, and north to Veracruz, Mexico; and on Hispaniola and Jamaica.

M. acacioi Marcus and Marcus, 1955. Brazil: Minas Gerais, Ouro Prêto, I Ioo m. Froehlich, I968.

$M$. geayi (Bouvier). French Guiana; on the Brazilian border. Colombia: Sierra Nevada de Santa Marta, seen; Sierra Nevada de Santa Marta, Cincinnati Coffee Plantation, seen. Panama: La Chorrera. Canal Zone: Barro Colorado Island, seen; Pedro Miguel; Balboa. Costa Rica; Osa Peninsula, Rincón, ro.viii.r1966, S. B. Peck, I under $\log$ at $400 \mathrm{ft}$., new record. Brues, I925; Clark, I9I3b; Clark and Zetek, I946.

M. guianensis (Evans). Guyana: east bank of Demerara River. 
M. insularis insularis Clark, 1937. Haiti: between Jacmel and Tronin.

M. insularis clarki Arnett, 196r. Jamaica: Portland Parish, 5 mi. SW Priestmans River, $\mathrm{r} 500 \mathrm{ft}$., seen.

M. ohausi (Bouvier). Brazil: near Rio de Janeiro; Petrópolis.

M. perrieri (Bouvier). Mexico: Veracruz.

M. torquatus (von Kennel). Trinidad: Port of Spain, seen; Maraval Valley, seen. Brues, I9r4.

\section{Oroperipatus Cockerell, I908}

Type species. Peripatus lankesteri Bouvier, 1899. Believed to be by subsequent designation of Clark, I913a. Original paper unavailable.

Distribution. The Pacific slope of tropical America from Tepic, Mexico, southward through Colombia, Ecuador, and Peru to Sorata, Bolivia, and in western Brazil.

O. balzani (Camerano). Bolivia: Coroico and Chulumani states.

O. belli (Bouvier). Ecuador: Durán, on Guayas River.

O. bimbergi (Fuhrmann), 1913. Colombia: Amagatal, 900-1800 $\mathrm{m}$; Guaduas, $800 \mathrm{~m}$. Fuhrmann, I9I4.

O. bluntschli Fuhrmann, I915. Peru: Río Samiria, I20 m. Zilch, I954b.

O. cameranoi (Bouvier). Ecuador: Cuenca; Sigsig.

O. corradoi (Camerano). Ecuador: Quito; Balzar; Guayaquil. Panama: El Ceremeño. Canal Zone: Barro Colorado Island, seen; Ancon. Venezuela: Falcón State, Paují Acosta District, H. G. Kugler, r.xi.r 945, 5, new record. Brues, 1925; Clark, 1914a, 1914b; Clark and Zetek, 1946.

O. ecuadoriensis (Bouvier). Ecuador: Bulim.

O.eiseni (Wheeler). Brazil: Rio Purus. Panama: El Cermeño; Panama City. Mexico: Tepic. Clark and Zetek, 1946; Furrmann, I9I4.

O. goudoti (Bouvier). Mexico.

O. intermedius (Bouvier). Bolivia: Sorata.

O. koepckei Zilch, 1954b. Peru: western side of Andes, $35 \mathrm{~km}$ from Olmos, toward Jaén, I $400 \mathrm{~m}$.

O. lankesteri (Bouvier). Ecuador: Paramba, near Quito.

O. multipodes (Fuhrmann), I913. Colombia, Río Amagá. Fuhrmann, I9I4.

O. omeyrus Marcus, 1952. Peru: San José de Lourdes, on Río Chirinos, Iooo m; Sahuayaco, between Abancay and Marcos, Urubamba valley, $800 \mathrm{~m}$. Zilch, I954b. 
O. (?)peruanus (Grube). Peru. Marcus, 1952; Zilch, I954b.

O. peruvianus Brues, I9I7. Peru: Tabaconás, near Huancabamba, $6000 \mathrm{ft}$., seen. Zilch, I954b.

O. quitensis (Schmarda). Ecuador: high regions.

O. soratanus (Bouvier). Bolivia: Sorata.

O.tuberculatus (Bouvier). Colombia: Popayán.

O.weyrauchi Marcus, 1952. Peru: Yurac on Río Aguaytia, 300 m. Zilch, 1954b.

Peripatus Guilding, I825, sensu stricto of Clark, I913a

Type species. Peripatus juliformis Guilding, I825. By monotypy. Distribution. West Indian Islands of Jamaica, Haiti, Puerto Rico, Vieques, St. Thomas, Antigua, Monserrat, Barbados, Guadeloupe, Dominica, and St. Vincent, and in South America in Brasil and from the mountains of western Venezuela westward to Colombia and north of Panama and Costa Rica.

$P$. antiguensis Bouvier. Antigua: Barlar, near Warburton. Monserrat. Clark, I929.

P. bavayi Bouvier. Guadeloupe.

P. bouvieri Fuhrmann, 1913. Colombia: Boca del Monte, near Bogotá; Cundinamarca Dept., above Aguadita, wet forest with ferns, 26.iii.r967, W. Brown, I, new record. Fuhrmann, I9I4.

P. brolemanni Bouvier. Venezuela: Tovar, near Mérida; Raxto Casselo; Puerto Cabello.

P. dominicae dominicae Pollard. Dominica: Laudat; Prince Rupert; Roseau, seen.

P. dominicae barbadensis Froehlich, 1962. Barbados: St. John, Codrington College.

P. dominicae basilensis Brues, I935. Haiti: Mount Basil, $4000 \mathrm{ft}$, seen. Dominican Republic: Mt. Diego de Ocampo, 3500-4000 ft., seen; north slope Loma Rucilla, $8000 \mathrm{ft}$., seen; north of Loma Rucilla, 6000-7000 ft., seen; Constanza, 3000-4000 ft., seen; Vic Valle Nuevo, $7000 \mathrm{ft}$., seen. Brues, 1935; 1939.

P. dominicae darlingtoni Brues, 1935. Haiti: Massif de la Hotte, between Camp-Perrin and Mafin, $3000 \mathrm{ft}$., seen.

P. dominicae haitensis Brues, I913. Haiti: Furcy (type locality); La Visite, La Selle Plateau, seen. Brues, 1935.

P. dominicae lachauxensis Brues, 1935. Haiti: Etang Lachaux, Massif de la Hotte, under Iooo ft., seen.

P. evelinae (Marcus), 1937. Brazil: between Canra Brava and Nova Roma, near border of Goiás and Minas Gerais. Froehlich, 1968. 
P. heloisae Carvalho, I94I. Brasil: Rio Tapirapé, near confluence with Rio Araguaia. Carvalho, 1942.

$P$. juliformis Guilding. St. Vincent.

P. juliformis danicus Bouvier. Virgin Islands: St. Thomas. St. Croix. St. John: along trail from Centerline Road to Cinnamon Bay, in litter in dry north-facing gully, 3.i.1967, S. Peck, I, new record. Brues, 1925 ; Clark, 1937.

P. juanensis Bouvier. Puerto Rico: Arecibo; Utuado; Vieques Island; El Yunque, May 1938, Darlington, $3000 \mathrm{ft} .$, I, new record; Manatí, 2.vi.1943, F. Mora, Indoors, I, new record; Toro Negro Forest Preserve, trail up Cerro Doña Juana, 28.xii.rg66, S. Peck, 6 on Fomes woody fungi bract on $\log$ on ground, $600 \mathrm{~m}$, new record, specimens lost. Clark, I9I3b; I913c.

P. manni Brues, I913. Haiti: Furcy; La Visite, La Selle Plateau, 5000-7000 ft., seen. Brues, 1935.

P. ruber Fuhrmann, I9I3. Panama: Chiriquí Prov., Lino, near Boquete, 4I00-4500 ft. Costa Rica: Rancho Redondo. Guatemala: Puerto Barrios (?). The record of $P$. (Epiperipatus) biolleyi var. betheli Cockerell 1913 from Puerto Barrios appears to be $P$. ruber according to Clark and Zetek (1946). Clark, I94Ib; Fuhrmann, I9I4.

P. sedgwicki Bouvier. Venezuela: Caracas, seen; San Esteban; La Moka; Las Trincheras; La Guayra.

P. swainsonae Cockerell. Jamaica: Bath; Savanna la Mar; localities in Hanover, Portland and Trelawny Parishes, from 400 to I 500 feet, seen. Andrews, I933; Arnett, I96I ; Brues, I9I I Lynn, 1936.

\section{Plicatoperipatus Clark, I913a}

Type species. Peripatus jamaicensis Grabham and Cockerell, I892. By original designation and by monotypy.

Known only from Jamaica.

P.jamaicensis (Grabham and Cockerell). Jamaica: Portland, Manchester, St. Thomas, Trelawny, St. Ann, and Westmorland Parishes, seen. Andrews, I933; Arnett, I961; Brues, I9II; Lynn, I936.

\section{Speleoperipatus new genus}

Description. Peripatidae, Peripatinae, with 22 or 23 pairs of legs; three foot papillae (two anterior and one posterior); legs four and five with urinary papillae broadly attached to and indenting creeping pad three, pad four crescent-shaped; no fifth pad.

Type species. Speleoperipatus speleus, new species. 


\section{Speleoperipatus speleus new species}

Holotype deposited in invertebrate collections of the Museum of Comparative Zoology, Harvard University. Type locality: Jamaica, Clarendon Parish, Pedro River, Pedro Great Cave. Type data: 20 December I972, S. B. Peck. Paratypes: all from same locality; one, 25 March I973, R. Norton and R. Zimmerman (deposited in Peabody Museum, Yale University); two, I7 August 1974, S. Peck and family, in Museum of Comparative Zoology.

Description. Eyes absent, no trace remaining. Depigmented; specimens in life pale, almost white, with a slight greenish-yellow cast (Fig. 8). Legs and "antennae" not appreciably elongated. Holotype $34 \mathrm{~mm}$ long, with 22 pairs of legs. Paratypes: One $27 \mathrm{~mm}$
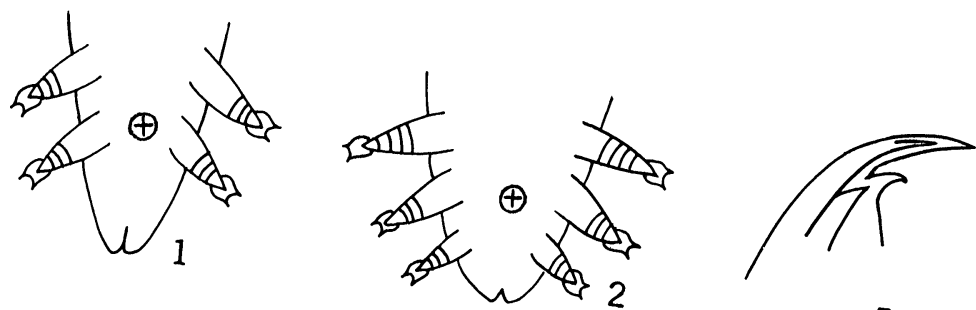

5
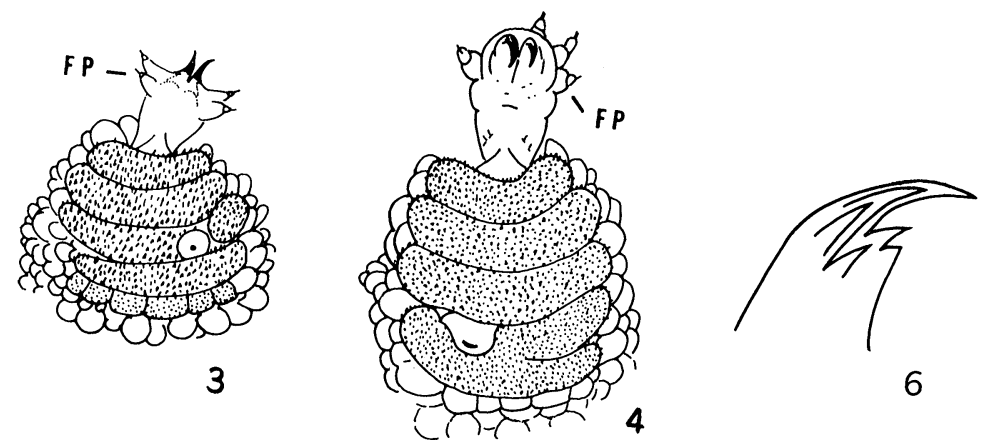

6

Figures 1-6. 1. Location of genital opening in Peripatopsidae, Peripatoidinae. 2. Location of genital opening in Peripatidae, Peripatinae. 3. Ventral surface of left fourth leg of Oroperipatus koepckei (after Zilch, 1954b) showing urinary papilla dividing the third band of the creeping pads, and four foot papillae (fp). 4. Ventral side of right fourth leg of Heteroperipatus engelhardi (after Zilch, 1954a) showing urinary papilla between creeping pads three and four, indenting pad four, and three anterior and one posterior foot papillae (fp). 5. Outer blade of right mandible of Speleoperipatus spelaeus. 6. Inner blade of right mandible of S. spelaeus. 


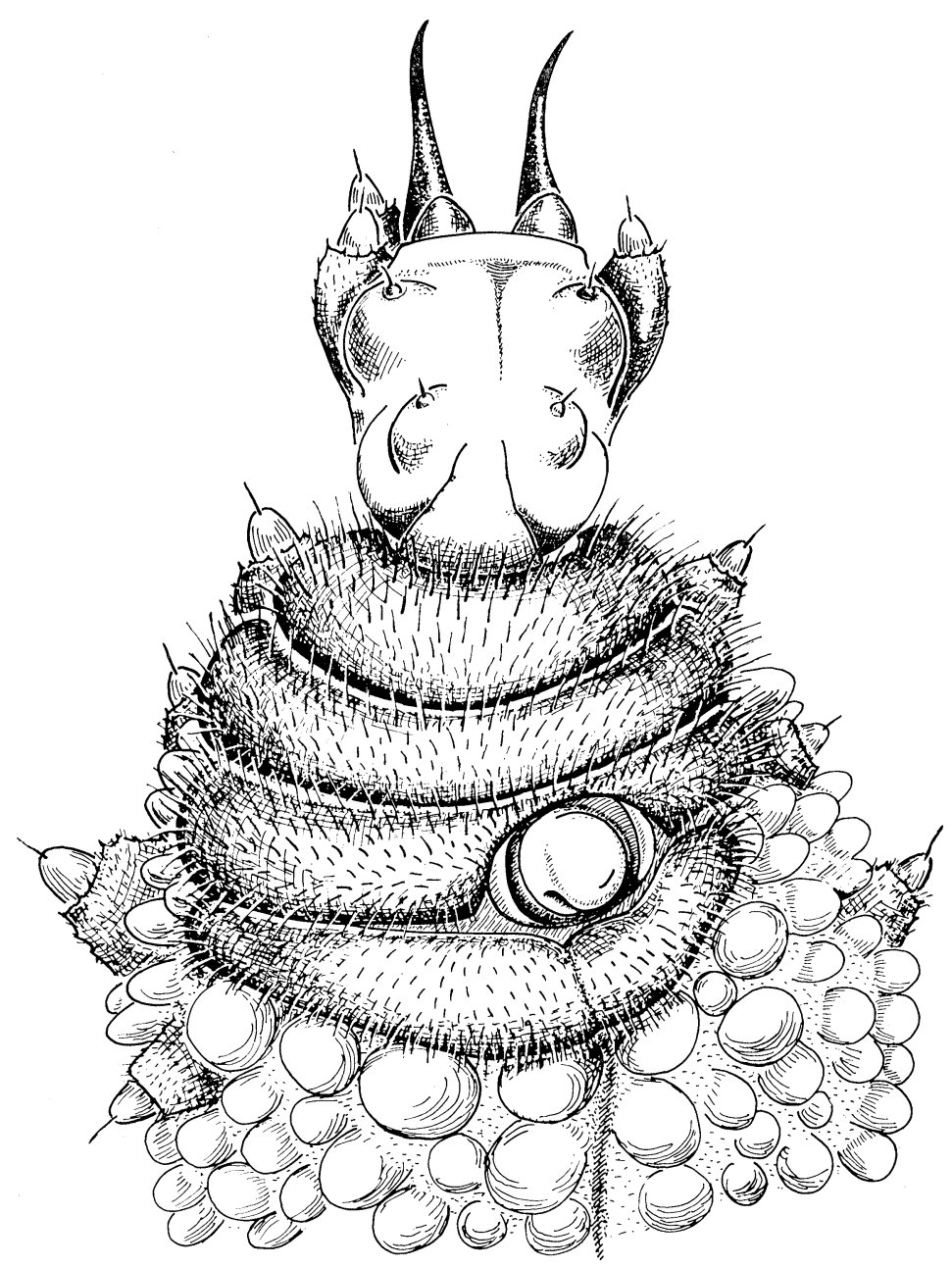

Figure 7. Left fourth leg of Speleoperipatus spelaeus.

long, with 23 legs on the left side and 22 on the right; a second $34 \mathrm{~mm}$ long with 22 pairs of legs, and the third $34 \mathrm{~mm}$ long with 23 pairs of legs. Widths 2 to $3 \mathrm{~mm}$ depending on preservation. All legs with four creeping pads; pad three broadly connected to urinary papillae in legs four and five; pad four crescent-shaped; all feet with two anterior and one posterior papilla (Fig. 7). 
Each body segment with 12 skin folds; folds neither diverging nor fusing along lateral side above the legs. The skin papillae with round bases but of varying sizes and shapes; lateral papillae with more elongate and straight-sided tip, tips shorter and more rounded on dorsal papillae; one to three but usually two small papillae between major papillae.

Mandible (Figs. 5, 6) outer blade with long thin main tooth and a short thin accessory tooth; inner blade with long, thin main tooth and two thin shorter accessory teeth. No small sawlike teeth below a diastema on outer or inner blade.

Type locality description and observations. The type locality cave is 1500 feet long, at I 700 feet elevation, o.6 air miles SE of the village of Pedro River, in northeastern Clarendon Parish. The cave is a large diameter, relatively simple, moist tunnel with large deposits of calcium carbonate dripstone and bat guano, and an air temperature of $2 \mathrm{I} .5^{\circ} \mathrm{C}$. All specimens were found near the middle of the cave in the "Three Ways" section (see map in Fincham and Ashton, 1967). One was found in the open on wet decomposed guano before, and the other three specimens in the chamber after, the low crawlway leading to Three Ways. In 1974, one specimen was sighted while it was partially exposed, feeding on an immature, blind Nelipophygus roach (Blatellidae), with most of its body hidden in a small hole at the side of a ceiling pocket. The second 1974 specimen was found hidden under a loose clay-guano flake formed by the drying of a formerly flooded section of the cave floor. Four people searched this chamber thoroughly for an hour in 1974 for more specimens but found none. A rich invertebrate fauna of potential prey exists in the cave. When touched, all specimens ejected a viscous, sticky fluid for $2-3 \mathrm{~cm}$ from their oral papillae.

Cave adaptation. The eyeless and depigmented conditions of the species are usually associated with troglobitic (cave-evolved) species, but are not limited to such species. These characters are also encountered in forest litter-evolved species, and many litter inhabitants in the past were certainly ancestral to presently troglobitic species (Barr, 1968). The legs and antennae of Speleoperipatus may be somewhat elongated (Fig. 8) as a specialization for cave life, but measurements (in life) of the appendages of this and epigean species are not available for comparison.

The general region of Jamaica from which Speleoperipatus comes is known to have several species of seemingly troglobitic invertebrates (personal observations), all of which have been derived from litterinhabiting ancestors. But collecting in forest litter in Jamaica is 


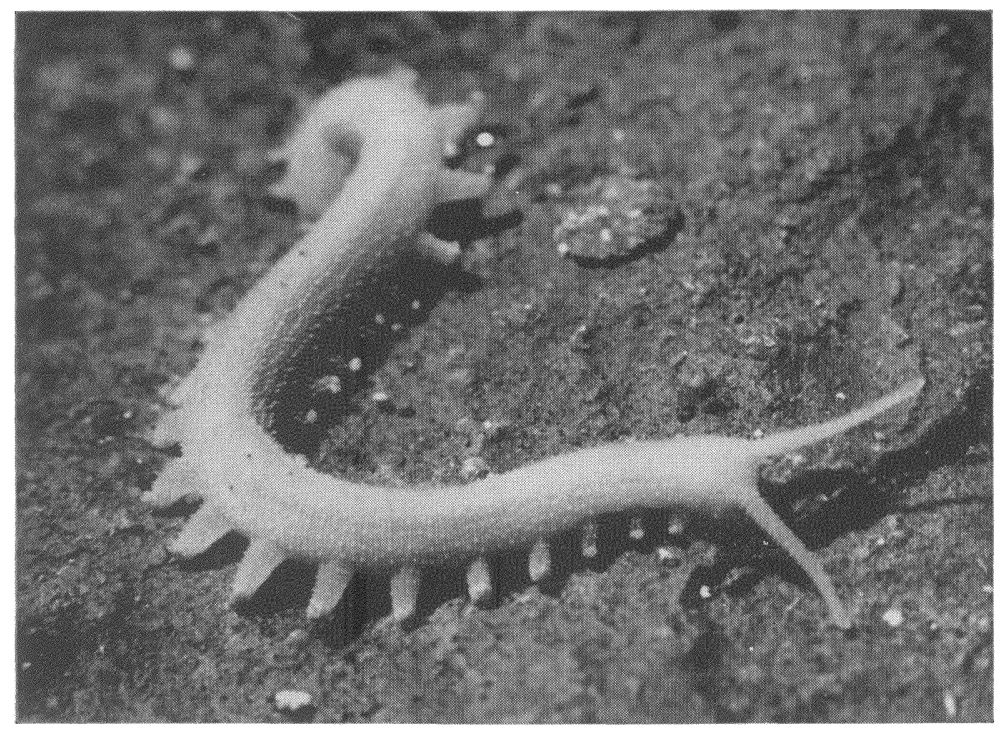

Figure 8. Speleoperipatus spelaeus in life.

inadequate so it is not known with certainty that the seemingly troglobitic species live only in caves. In my field work on Jamaican cave faunas, I have made some 70 visits to some 50 caves in search of their invertebrates, and Russell M. Norton has made some 20 visits to some 20 caves (many of the same caves in which I have collected). Since many of the other troglobitic species have been encountered in many of these caves over much of Jamaica and Speleoperipatus has not, it is possible that this genus may now be limited to a single cave system. And since it may exist only in small numbers, future collecting of it should be restrained, in order to preserve this unique genus from extinction.

Discussion. The genus and species is close to both Epiperipatus and Peripatus (s.str.) in its skin papillae; and to these and Macroperipatus in the number of feet papillae ( 2 anterior and I posterior in all these genera), and four foot creeping pads (as in all these genera). However, the new genus differs from these genera in having some four fewer (at least) pairs of legs, and in the mandibles.

In some respects, the new genus and species resembles Typhloperipatus williamsoni Kemp (19I4) from the Himalaya foothills of eastern India (near Rotung, on the Dihang River, Assam, near Tibet). Both are eyeless, and the latter has only i9 to 20 pairs of 
legs. The latter species was taken abundantly in leaf litter in scrubjungle at from $\mathrm{I} 200$ to 2000 feet elevation. However, eyelessness and loss of legs are characters that can be convergently acquired, and the two genera are presently placed in different subfamilies, based on the number of foot papillae (three and more in Peripatinae of the New World and equatorial Africa, and only two in the Eoperipatinae (containing Eoperipatus and Typhloperipatus in the IndoMalaysian area). Kemp (I9I4: 49I) lists other features uniting Typhloperipatus with New World genera more closely than with Malaysian Eoperipatus, but this relationship should be reviewed.

A low number of legs may be a primitive feature in the Peripatidae. In comparison to the 22 or 23 pairs in S. spelaeus, 23 (to 27) pairs occur in Mesoperipatus tholloni of equatorial Africa, and 23 (to 29) pairs occur in some species groups of Oroperipatus. However, in all other New World genera, 27 pairs seems to be the lowest number.

In conclusion, the genus Speleoperipatus, because of its intermediate characteristics involving Asian and African as well as New World genera, seems to have originated from an ancient lineage of onychophorans in which the characters were not as well segregated as they are at present. In this case, Speleoperipatus, Mesoperipatus and Typhloperipatus of the Peripatidae can be regarded as relicts of earlier more widespread groups. The eyelessness of Typhloperipatus shows that this feature can be associated with species that do not live in caves. Speleoperipatus may thus have become eyeless before it entered a cave habitat, but until it is found in a non-cave habitat (such as forest litter or talus slopes), it should be considered as a troglobitic cave-limited species. It is worth noting, in closing, that the two families of the Phylum have once each, and independently, entered and permanently occupied a cave habitat and may have become restricted to, and specialized for, this cave habitat.

\section{AcKNowledgements}

My wife, Jarmila, prepared the illustrations, and helped in field work in Jamaican caves in 1972 and 1974 , as did our daughters Olga and Hana in 1974. This field work, as well as that of Russell M. Norton of Yale University in 1973, was partially supported by my Canadian National Research Council operating grants. Bernard C. Lewis, Thomas Farr, and George R. Proctor of the Institute of Jamaica (Kingston) provided various assistance and help in Jamaica, and Dr. Farr allowed examination of the collections in the Institute. 
Dr. Herbert Levi, Museum of Comparative Zoology, permitted study of the specimens in the collections under his care. The manuscript was reviewed by Henry Townes and Herbert W. Levi.

\section{Literature Cited}

Andrews, E. A.

1933. Peripatus in Jamaica. Quart. Rev. Biol., 8: 155-163. ARNETT, R. H.

1961. The Onychophora of Jamaica. Ent. News, 72: 213-220. BARNES, $R$.

1968. Invertebrate Zoology. Saunders, Philadelphia. 743 pp.

BARR, T. C.

1968. Cave ecology and the evolution of troglobites. In: T. Dobzhansky, M. Hecht, W. Steere, eds. Evolutionary Biology, Appleton-

BOUvier, E. L. Century-Crofts, New York. v. 2: 35-102.

1905. Monographie des Onychophores. I. Ann. Sci. Nat. Zool. (ser. 9), 2: 1-383.

1906. Le Peripatus edwardsi au Bresil. Bull. Soc. Ent. France, 1906: 268.

1907. Monographie des Onychophores. II. Ann. Sci. Nat. Zool. (ser. 9), 5: 61-318.

1908. Sur le Peripatus brasiliensis Bouv. Soc. Philomathique Bull. (ser. 9), $10: 50$.

1928. À propos des observations du Fr. Claude-Joseph sur un peripate BRINCK, P. du Chili. Ann. Sci. Nat., Zool. (ser. 10), 11: 126.

1956. Onychophora, a review of the South African species, with a discussion on the significance of the geographical distribution of the group. In: B. Hanstrom, P. Brinck, G. Rudebeck, eds., South African Animal Life, Results of the Lund University Expedition 1950-1951. Almquist and Wiksells, Uppsala. V. 4: 7-32.

BRUES, C. T.

1911. A new species of Peripatus from Grenada, with observations on other species of the genus. Bull. Mus. Comp. Zool., 54: 305318,2 plates.

1913. Preliminary descriptions of two new forms of Peripatus from Haiti. Bull. Mus. Comp. Zool., 54: 519-521.

1914. A new Peripatus from Colombia. Bull. Mus. Comp. Zool., 58: 375-382.

1917. A new species of Peripatus from the mountains of northern Peru. Bull. Mus. Comp. Zool., 61: 383-387.

1923. The geographical distribution of the Onychophora. Amer. Nat., 57: 210-217.

1925. Notes on Neotropical Onychophora. Psyche, 32: 159-165.

1935. Varietal forms of Peripatus in Haiti. Psyche, 42: 58-62.

1939. Additional records of Onychophora from the island of Haiti. Psyche, 46: 36-37. 
Brues, C. T., A. L. Melander, F. M. Carpenter

1954. Classification of Insects. Bull. Mus. Comp. Zool., 108: 917 pp. Carvalho, A. Leitao de

1941. Nota prévia sôbre uma nova espécie de "Peripatus" do Brasil central. Rev. Brasil. Biol., 1: 447-448.

1942. Sôbre "Peripatus heloisae," do Brasil Central. Bol. Mus. Nac., Rio de Janeiro (n. ser.), Zool., 2: 57-73.

Clark, A. H.

1913a. A revision of the American species of Peripatus. Proc. Biol. Soc. Wash., 26: 15-20.

1913b. Notes on American species of Peripatus, with a list of the known forms. Smithsonian Misc. Coll., 60(17), 5 pp.

1913c. Piccole note su degli Onychophora. Zool. Anz., 42: 253-254.

1914a. Notes on some specimens of a species of Onychophore (Oroperipatus corradoi) new to the fauna of Panama. Smithsonian Misc. Coll., $63(2): 1-2$.

1914b. On some onychophores (Peripatus) from the Republic of Panama. Zool. Anz., 45: 145-146.

1915a. The present distribution of the Onychophora, a group of terrestrial invertebrates. Smithsonian Misc. Coll., 65(1): $25 \mathrm{pp}$.

1915b. A note on the occurrence of Epiperipatus imthurmi (Sclater). Proc. Biol. Soc. Washington, 28 : 182.

1929. Peripatus from the island of Montserrat. Proc. Ent. Soc. Washington, 31: 139.

1937. On some Onychophores from the West Indies and Central America. Proc. United States Nat. Mus., $85: 1-3$.

Clark, A. H. and J. Zetek

1946. The Onychophores of Panama and the Canal Zone. Proc. United States Nat. Mus., 96: 205-213.

Claude-Joseph, $\mathrm{H}$.

1927. Observaciones sobre el Peripatus Blainvillei Bl. Rev. Chilena Hist. Nat., 31: 223-236.

1928. Observations sur un Péripate du Chile. Ann. Sci. Nat., Zool. (ser. 10), 11: 285-298.

Cockereli, T. D. A.

1913. A Peripatus from Guatemala. Proc. Biol. Soc. Washington, 26: 87-88.

Cú́Not, $\mathrm{L}$.

1949. Les Onychophores. In: P. Grassé, ed., Traité de Zoologie. Masson et Cie., Paris, 6: 3-37.

Darlington, P. J.

1965. Biogeography of the Southern End of the World. Harvard University Press, Cambridge, Mass. 326 pp.

DUNN, E.

1943. Zoological results of the Azuero Peninsula Panama expedition of 1940. Part 1. - A new species of Peripatus. Notulae Naturae $123: 5 \mathrm{pp}$.

Fincham, A. and K. Ashton

1967. The University of Leeds Hydrological Expedition to Jamaica, 1963. Cave Research Group Great Britain Trans., 9(1): 60 pp. 
Froehlich, C. G.

1962. A Peripatus from Barbados. Boll. Fac. Fil. Ciênc. Letr., Univ. S. Paulo, no. 261. Zoologia no. 24: 325-334, 2 plates.

1968. On some Brazilian Onychophores. Beiträge zur Neotropischen Fauna, 5(3): 160-171.

Fuhrmann, $O$.

1913. Uber einige neue neotropische Peripatus-Arten. Zool. Anz., 42: 241-249.

1914. Quelques nouveaux Péripates americains. Mem. Soc. Neuchatel Sci. Nat., 5: 176-192.

1915. Uber eine neue Peripatus-Art vom Oberlauf des Amazonas. Abh. Senckenbergische naturf. Gesellschaft, 36: 277-283.

Gravier, C. and L. Fage

1925. Sur une nouvelle espéce de Péripate du Chili. Ann. Sci. Nat., Zool. (ser. 10), 8: 185-200.

Hutchinson, G. E.

1928. Observations on South African Onychophora. Ann. S. African Mus., 25: 337-340.

Joноw, F.

1911. Observaciones sobre los Onicóforos Chilenos. Bol. Mus. Nac. Chile, 3 : 79-97.

KAESTNer, A.

1968. (transl. adapt. H. \& L. Levi). Invertebrate Zoology, vol. 2, Arthropod relatives, Chelicerata, Myriapoda. Wiley Interscience, New York. $472 \mathrm{pp}$.

KEMP, S.

1914. Onychophora. Zoological results of the Abor Expedition, 19111912. Records of the Indian Museum (Calcutta), 8: 471-492, plates 34-37.

L.AWRENCE, R. F.

1931. A new Peripatopsid from the Table Mountain Caves. Ann. South African Mus., 30: 101-107.

LYNN, W.

1936. A new location for Peripatus in Jamaica. Psyche, 43 : 119-125. Marcus, ERnST

1937. Um Onychophoro novo, Peripatus (Epiperipatus) evelinae spec. nov. de Goyaz. Rev. Mus. Paulista, São Paulo, 21: 905-910.

Marcus, Eveline

1952. On South American Malacopoda. Bol. Fac. Fil. Ciên. Letr., Univ. S. Paulo Zool., no. 17, 188-194.

Marcus, Eveline and Ernesto Marcus

1955. A new Peripatus from Minas Gerais, Brazil. Anais Acad. Brazil. Ciên., 27 : 189-193.

Picado, M.

1911. Sur un habitat nouveau des Peripatus. Bull. Mus. Nat. d'Hist. Nat., 17: 415-416.

SEDGWICK, A.

1908. The distribution and classification of the Onychophora. Quart. J. Micros. Sci., 52 : 479-506. 
ZACHER, F.

1933. Onychophora. In: Handbuch der Zoologie (Kükenthal); De Gruyter, Berlin, $3(2)$ : 73-138.

ZiLch, A.

1954a. Onychophoren aus El Salvador. Senckenbergiana biol., 35: 147-150.

1954b. Ein neuer Oroperipatus aus Peru (Onychophora). Senckenbergiana biol., $35:$ 151-154. 

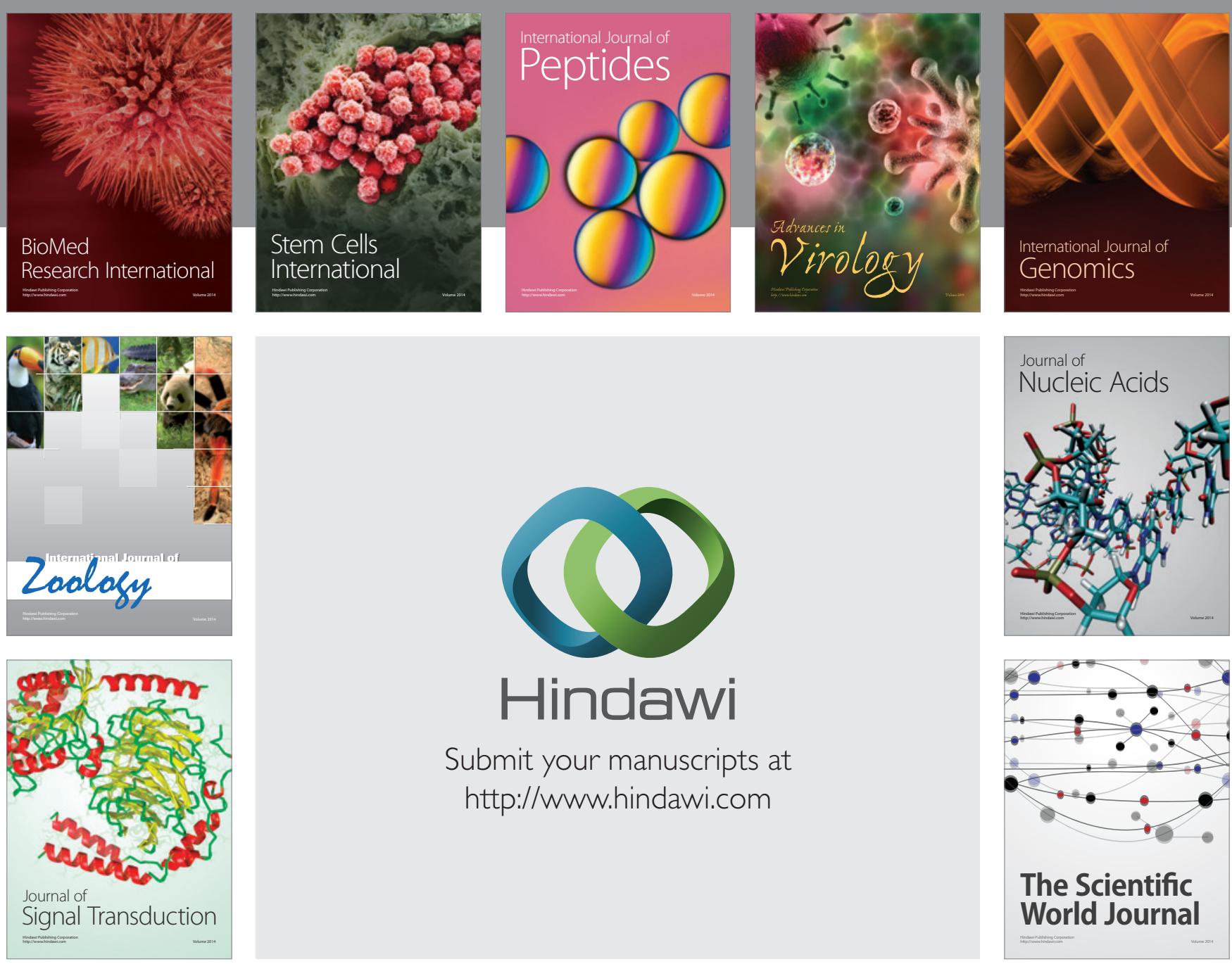

Submit your manuscripts at

http://www.hindawi.com
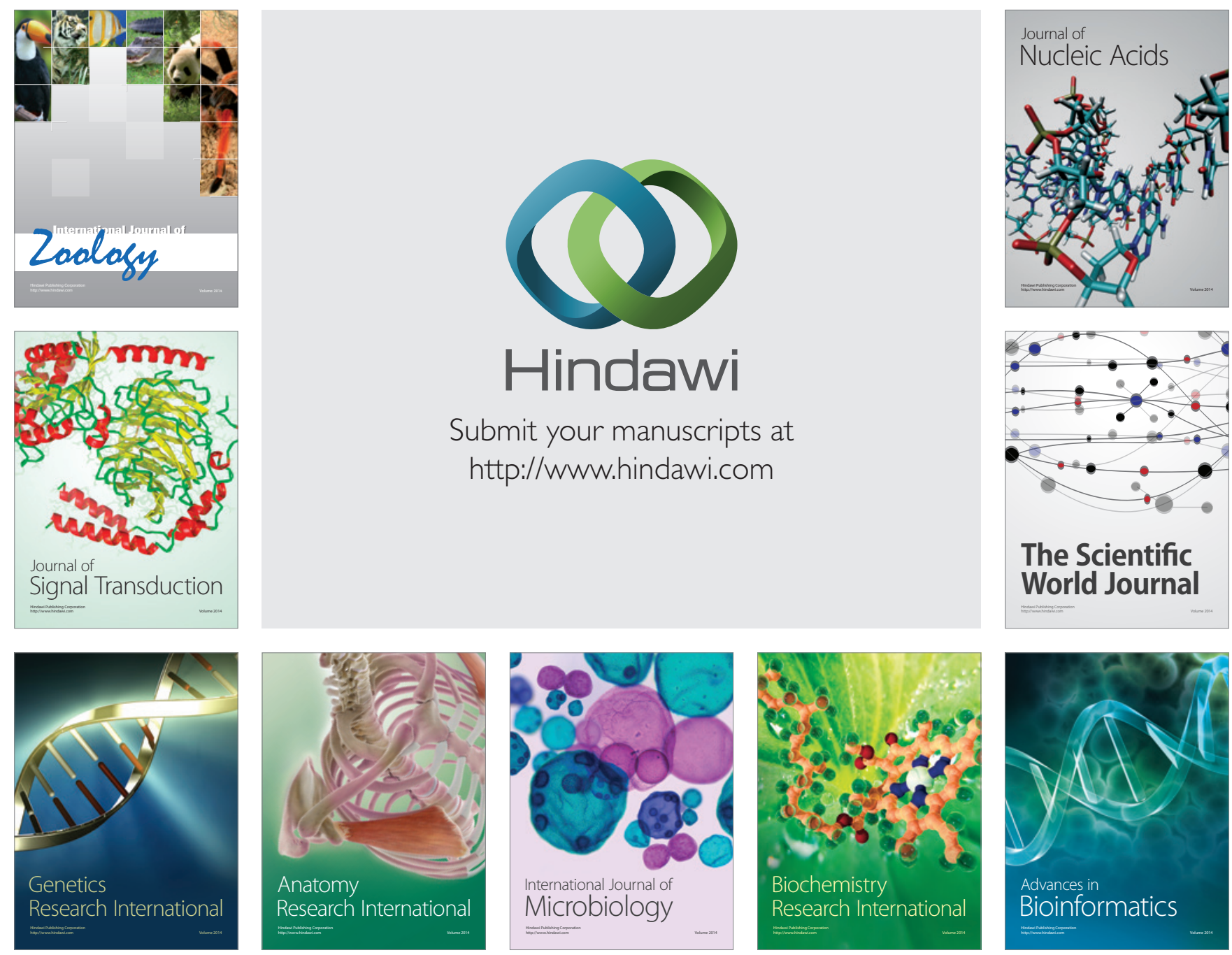

The Scientific World Journal
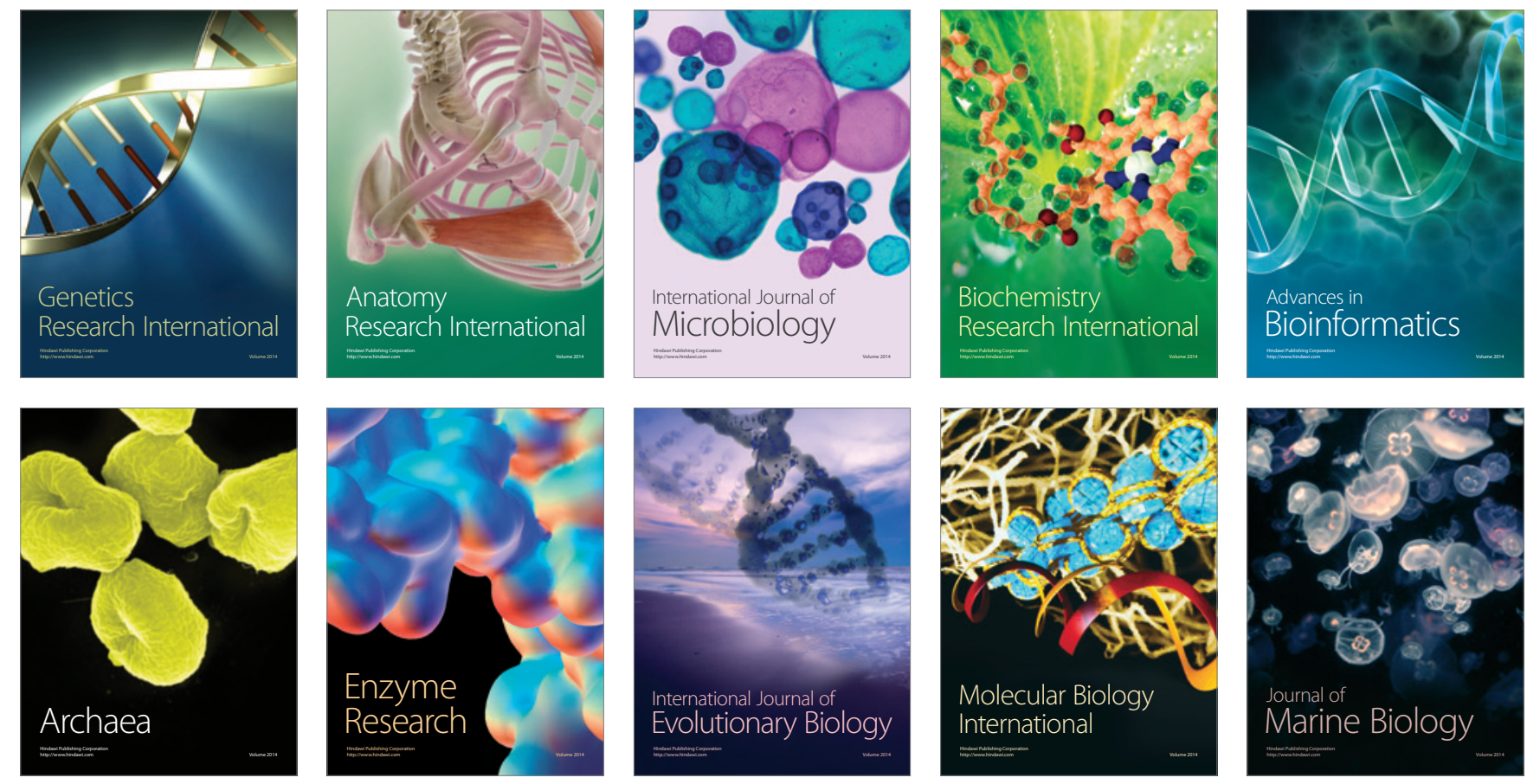